\title{
Synthesis of Ru-B amorphous alloy supported on SBA-15 with excellent catalytic efficiency in maltose hydrogenation
}

\author{
WANG Yi, XU Liang, XU Lei, LI Hexing, LI Hui* \\ The Education Ministry Key Lab of Resource Chemistry and Shanghai Key Laboratory of Rare Earth Functional Materials, \\ Shanghai Normal University, Shanghai 200234, China
}

A R T I C L E I N F O

Article history:

Received 3 December 2012

Accepted 8 January 2013

Published 20 May 2013

\section{Keywords:}

Ruthenium

Boron

Amorphous alloy

Mesoporous silica

Hydrogenation

Maltose

Maltitol

\section{A B S T R A C T}

Mesoporous silica (SBA-15)-supported Ru-B catalyst was synthesized by ultrasound-assisted incipient wetness infiltration of $\left(\mathrm{NH}_{4}\right)_{2} \mathrm{RuCl}_{6}$ into SBA-15 and a subsequent reduction with $\mathrm{BH}_{4}^{-}$. It was characterized by X-ray diffraction, X-ray photoelectron spectroscopy, differential scanning calorimetry, and transmission electron microscopy. The resulting Ru-B-X/SBA-15 catalyst was identified to be an amorphous alloy highly dispersing within the pore channels of SBA-15. During liquid-phase maltose hydrogenation, the as-synthesized Ru-B-X/SBA-15 catalyst was more active than the $\mathrm{Ru}-\mathrm{B}-\mathrm{C} / \mathrm{SBA}-15$ obtained via the same process but using $\mathrm{RuCl}_{3}$ as the metal source. The as-prepared $\mathrm{Ru}-\mathrm{B}-\mathrm{X} / \mathrm{SBA}-15$ delivered catalytic activity up to seven times greater than that associated with the reference unsupported Ru-B-C catalyst prepared through the reduction of $\mathrm{RuCl}_{3}$ with $\mathrm{BH}_{4}$, and could be used repetitively 11 times without significant deactivation.

(C) 2013, Dalian Institute of Chemical Physics, Chinese Academy of Sciences. Published by Elsevier B.V. All rights reserved.

\section{Introduction}

Hydrogenation of maltose to maltitol (Scheme 1) is of great importance because of the potential application of maltitol as a sugar substitute in modern nutrition, in diabetic food, and as an intermediate for pharmaceutical production [1]. Presently, Raney Ni is used in this industrial process [2]. However, the leaching of nickel during hydrogenation and the poor selectivity to maltitol make this catalyst less profitable. A refilling of the catalyst and a purification of product to remove residual $\mathrm{Ni}$ and other byproducts are necessary, which eventually increase the overall cost [3]. Amorphous alloys, metastable materials with long-range disordered but short-range ordered structure, have attracted growing attention from both academia and industry because of their superior catalytic properties to their crystal- line counterparts [4,5]. Ru-based amorphous alloy has proved to be a potential alternative to Raney $\mathrm{Ni}$ in selective hydrogenations of benzene to cyclohexene [6], glucose to sorbitol [7], and maltose to maltitol [8]. Generally, Ru-B amorphous alloy was prepared by the reduction of $\mathrm{Ru}^{3+}$ with $\mathrm{BH}_{4}^{-}$in aqueous solution [4]. However, vigorous and exothermic reactions between metallic ions and $\mathrm{BH}_{4}^{-}$usually induce particle aggregation, thereby reducing catalytic activity. Recently, we have developed an approach to synthesizing monodispersed Ru-B amorphous alloy through ultrasound-assisted chemical reduction of $\left(\mathrm{NH}_{4}\right)_{2} \mathrm{RuCl}_{6}$ with $\mathrm{BH}_{4}{ }^{-}$in aqueous solution [9]. The coordination of halide ligands to $\mathrm{Ru}^{3+}$ resulted in the formation of $\mathrm{ul}$ trafine Ru-B amorphous alloy with high dispersion, which exhibited much higher catalytic activity relative to the $\mathrm{Ru}-\mathrm{B}$ prepared by reduction of $\mathrm{Ru}^{3+}$ with $\mathrm{BH}_{4}^{-}$. However, their industrial

\footnotetext{
* Corresponding author. Tel: +86-21-64322642; Fax: +86-21-64322272; E-mail: lihui@shnu.edu.cn This work was supported by the National Natural Science Foundation of China (21273149), the Program for New Century Excellent Talents in University (NCET-11-1052), and the Shanghai Science \& Technology and Education Committee (11JC1408900, 12490502800, 10SG41, 12YZ084). DOI: 10.1016/S1872-2067(12)60526-9 | http://www.sciencedirect.com/science/journal/18722067 | Chin. J. Catal., Vol. 34, No. 5, May 2013
} 

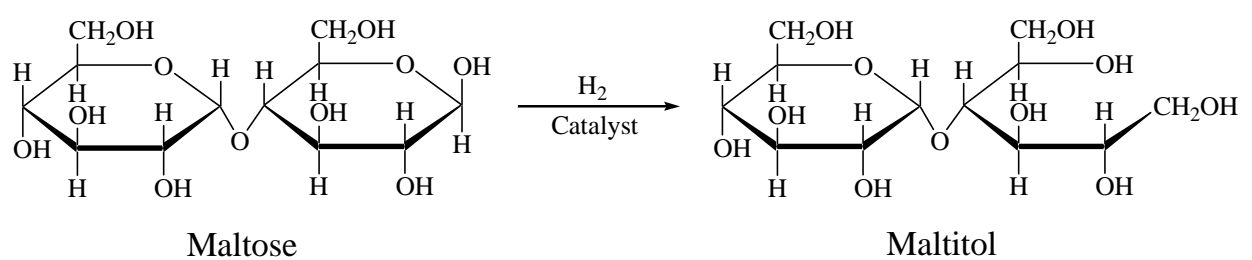

Scheme 1. Catalytic hydrogenation of maltose to maltitol.

application is still limited because of the high cost of $\mathrm{Ru}$, as well as the low surface area and poor thermal stability of Ru-B amorphous alloy. The development of supported Ru-B amorphous alloy catalysts with improved thermal stability seems a promising option.

Because of high surface areas, ordered pore channel, and uniformity in pore size, highly ordered mesoporous materials can act as promising carriers for depositing amorphous alloy nanoparticles [10]. However, the supported amorphous alloy made with pure mesoporous silica usually exhibits non-uniform distribution and even blockage of the pore entrance, which eventually limits the activity. Although the metal dispersion can be improved through the modification of the surface of mesoporous silica (SBA-15) with hydrophobic functional groups [11], this approach involves a complicated preparation process. With the aim of designing powerful catalysts for maltose hydrogenation to maltitol, we report the synthesis of supported $\mathrm{Ru}-\mathrm{B}$ amorphous alloy through ultrasound-assisted incipient wetness infiltration of $\left(\mathrm{NH}_{4}\right)_{2} \mathrm{RuCl}_{6}$ into SBA-15 and a subsequent reduction with $\mathrm{BH}_{4}$. This product exhibited much higher activity and improved durability than the conventionally prepared $\mathrm{Ru}-\mathrm{B}$ amorphous alloys during maltose hydrogenation. The correlation of the catalytic performances to the structural properties has been tentatively established.

\section{Experimental}

\subsection{Catalyst preparation}

SBA-15 silica was synthesized according to the method reported by Zhao et al. [12]. The supported $\mathrm{Ru}-\mathrm{B}$ catalyst was prepared by the following procedure. SBA-15 (1.0 g) was impregnated with $8 \mathrm{ml}$ of $\left(\mathrm{NH}_{4}\right)_{2} \mathrm{RuCl}_{6}$ aqueous solution $(0.062$ $\mathrm{mol} / \mathrm{L})$, which was sonicated for $2 \mathrm{~h}$ with an ultrasonic bath (60 W). After being calcined at $473 \mathrm{~K}$ for $2 \mathrm{~h}, 1.5 \mathrm{ml}$ of $\mathrm{KBH}_{4}$ aqueous solution ( $2.0 \mathrm{~mol} / \mathrm{L})$ was added dropwise at $273 \mathrm{~K}$ and was stirred continuously until no bubbles were released. The solid was washed free from $\mathrm{Cl}^{-}$and $\mathrm{K}^{+}$ions with deionized water until a $\mathrm{pH} \sim 7$ was achieved. The as-prepared $\mathrm{Ru}-\mathrm{B}$ sample was denoted as Ru-B-X/SBA-15, with $\mathrm{X}$ representing the metal source, $\left[\mathrm{RuCl}_{6}\right]^{2-}$ complexes.

For comparison, the reference Ru-B catalysts were prepared through the conventional method. Unsupported Ru-B amorphous alloy was prepared by direct reduction of $\mathrm{RuCl}_{3}$ with $\mathrm{BH}_{4}{ }^{-}$, which was denoted as Ru-B-C. Supported Ru-B amorphous alloy was prepared by the same process as described above for $\mathrm{Ru}-\mathrm{B}-\mathrm{X} / \mathrm{SBA}-15$, except that $\mathrm{RuCl}_{3}$ was used as the metal source and was denoted as Ru-B-C/SBA-15. Raney Ni was commercially available and was used without further treatment.

\subsection{Catalyst characterization}

The bulk composition was analyzed by means of inductively coupled plasma optical emission (ICP, Varian VISTA-MPX). The amorphous structure was investigated by both X-ray diffraction (XRD, Rigaku D/Max-RB with $\mathrm{Cu} K_{\alpha}$ radiation) and selected-area electronic diffraction (SAED, JEOL JEM-2100). The crystallization process was followed by differential scanning calorimetry (DSC, Shimadzu DSC-60) under an $\mathrm{N}_{2}$ atmosphere at the heating rate of $10 \mathrm{~K} / \mathrm{min}$. The surface morphology and the particle size were observed by transmission electron microscopy (TEM, JEOL JEM-2100). The surface electronic states were investigated by X-ray photoelectron spectroscopy (XPS, ULVAC-PHI PHI5000 VersaProbe using $\mathrm{Al} K_{\alpha}$ radiation), during which all Ru-B samples were dried and pretreated in situ in pure Ar atmosphere to avoid oxidation. The active surface area ( $A_{\text {act }}$ ) was measured by hydrogen chemisorption on a Micromeritics AutoChem II 2920 system assuming $\mathrm{H} / \mathrm{Ru}(\mathrm{s})=1$ and a surface area of $6.1 \times 10^{-20} \mathrm{~m}^{2}$ per Ru atom.

\subsection{Activity test}

The liquid-phase hydrogenation of maltose was performed at 3.0 MPa of $\mathrm{H}_{2}$ pressure and $373 \mathrm{~K}$ in a 200-ml stainless steel autoclave with a Teflon tube to avoid metal contamination, in which $\mathrm{Ru}(0.05 \mathrm{~g}, 0.5 \mathrm{mmol})$ and a maltose aqueous solution ( $40 \% \mathrm{w} / \mathrm{w}$ in $50 \mathrm{ml} \mathrm{H}_{2} \mathrm{O}$ ) were well mixed. According to the drop of the $\mathrm{H}_{2}$ pressure in the autoclave with reaction time, both the specific activity (the $\mathrm{H}_{2}$ uptake rate per gram of $\mathrm{Ru}$, $R_{\mathrm{H}^{\mathrm{m}}}, \mathrm{mmol} /(\mathrm{h} \cdot \mathrm{g})$ ) and the intrinsic activity (the $\mathrm{H}_{2}$ uptake rate per $\mathrm{m}^{2}$ of $\left.\mathrm{Ru}, R_{\mathrm{H}} \mathrm{S}, \mathrm{mmol} /\left(\mathrm{h} \cdot \mathrm{m}^{2}\right)\right)$ were calculated using the ideal gas equation. After reaction for $0.5 \mathrm{~h}$, the reaction products were analyzed in a liquid-phase chromatograph (Agilent 1100) equipped with a carbohydrate column (CARBOSep, Coregel-87C) and a refractive index detector at $353 \mathrm{~K}$ with water as the movable phase at $0.6 \mathrm{ml} / \mathrm{min}$. Preliminary kinetic studies revealed the following: that there was a plateau in the dependency of the reaction initial rate when the stirring rate was above $1000 \mathrm{r} / \mathrm{min}$; and that the reaction initial rate varied linearly with the catalyst amount from 0.1 to $2.0 \mathrm{~g}$, indicating that the stirring rate of $1200 \mathrm{r} / \mathrm{min}$ was high enough that the hydrogenation rates were independent of mass transfer.

\section{Results and discussion}

\subsection{Catalyst characterization}




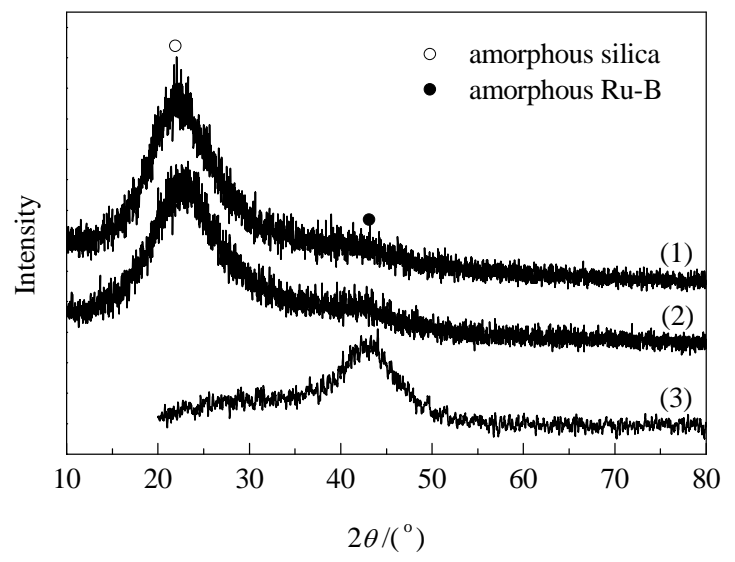

Fig. 1. Wide-angle XRD patterns of catalysts. (1) Ru-B-X/SBA-15; (2) Ru-B-C/SBA-15; (3) Ru-B-C.

The wide-angle XRD patterns (Fig. 1) demonstrated that, besides a broad peak around $2 \theta=22^{\circ}$ corresponding to amorphous $\mathrm{SiO}_{2}$, both $\mathrm{Ru}-\mathrm{B}-\mathrm{X} / \mathrm{SBA}-15$ and $\mathrm{Ru}-\mathrm{B}-\mathrm{C} / \mathrm{SBA}-15$ displayed only one broad peak around $2 \theta=45^{\circ}$ indicative of the typical amorphous structure [7]. Figure 2 shows the XPS spectra of the as-prepared supported Ru-B catalysts. Because the core-level at $\mathrm{Ru} 3 d_{3 / 2}$ was overlapped with that of $\mathrm{C} 1 s$ [13], the core-level at the $\mathrm{Ru} 3 d_{5 / 2}$ peak was chosen to determine the electronic state of the Ru species. Only one peak with the binding energy (BE) at $c a .280 .0 \mathrm{eV}$ was observed in the $\mathrm{Ru} 3 d_{5 / 2}$ level, indicating that almost all the Ru species were present as the metallic state in both samples [14]. However, the B species were present in both the elemental $\mathrm{B}$ and the oxidized $\mathrm{B}$, with $\mathrm{B} 1 \mathrm{~s} \mathrm{BE}$ values of around 188.3 and $192.9 \mathrm{eV}$. The B $1 s$ BE of the elemental B in either Ru-B-X/SBA-15 or Ru-B-C/SBA-15 exceeded that of pure $\mathrm{B}(187.1 \mathrm{eV})$ [15] by $1.2 \mathrm{eV}$, further indicating that the elemental B is alloyed with the metallic Ru. In alloys, partial electrons may be transferred from $\mathrm{B}$ to $\mathrm{Ru}$, as has been detected in other M-B samples [15]. The failure in observing the BE shift of the metallic Ru can be understood by considering its relatively greater atomic weight compared with the B atom [15]. The combined results from both the XPS and the aforementioned XRD demonstrated that both Ru-B-X/SBA-15 and Ru-B-C/SBA-15 were present in the Ru-B amorphous alloys. Although ICP analysis demonstrated that Ru-B-X/SBA-15 dis-

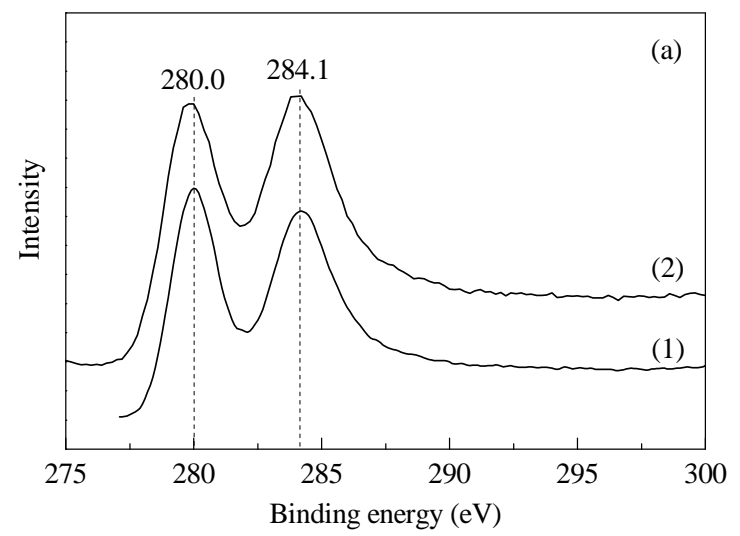

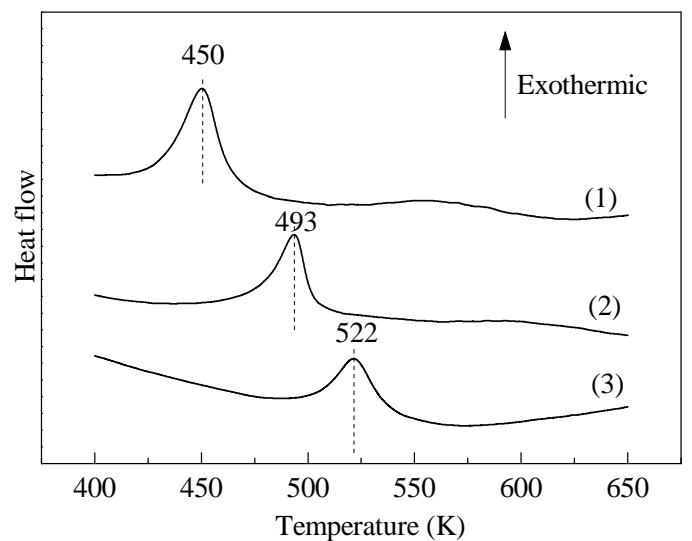

Fig. 3. DSC curves of catalysts. (1) Ru-B-C; (2) Ru-B-C/SBA-15; (3) Ru-B-X/SBA-15.

played a similar bulk composition to $\mathrm{Ru}-\mathrm{B}-\mathrm{C} / \mathrm{SBA}-15$ (see Table 1), the XPS analysis revealed that Ru-B-X/SBA-15 exhibited a higher surface molar ratio of the alloying $\mathrm{B}$ to the metallic $\mathrm{Ru}$ (19/81) than Ru-B-C/SBA-15 (12/88), which was similar to Ru-B-C (11/89) [9]. This observation implied that Ru-B prepared using $\left(\mathrm{NH}_{4}\right)_{2} \mathrm{RuCl}_{6}$ as the ruthenium source was surface-enriched with alloying $B$. The higher $B$ content in $\mathrm{Ru}-\mathrm{B}-\mathrm{X} / \mathrm{SBA}-15$, relative to those in $\mathrm{Ru}-\mathrm{B}-\mathrm{C}$ and $\mathrm{Ru}-\mathrm{B}-\mathrm{C} / \mathrm{SBA}-15$, may be due to the inhibition of $\mathrm{BH}_{4}{ }^{-}$hydrolysis by the coordination of $\mathrm{Cl}$, which would enhance the acidity of the reaction solution and the formation of B-enriched amorphous alloys [9]. The crystallization process was further investigated by DSC analysis. As shown in Fig. 3, Ru-B-X/SBA-15 and Ru-B-C/SBA-15 displayed exothermic peaks at 522 and $493 \mathrm{~K}$, much higher than that of $\mathrm{Ru}-\mathrm{B}-\mathrm{C}$. The enhanced thermal stability could be due to the stabilizing effect of the support. Additionally, Ru-B-X/SBA-15 exhibited stronger thermal stability against crystallization than $\mathrm{Ru}-\mathrm{B}-\mathrm{C} / \mathrm{SBA}-15$. This is related to the increased surface $\mathrm{B}$ content in Ru-B alloys. On the other hand, the location of the uniform Ru-B nanoparticles in the channel of the carrier may inhibit the particle migration and agglomeration, a key step in the crystallization process [16].

The low-angle XRD patterns (Fig. 4) revealed that the pure SBA-15 and the supported Ru-B samples displayed an intense (100) diffraction peak at $2 \theta=0.77^{\circ}$ and two weak peaks at $2 \theta=$

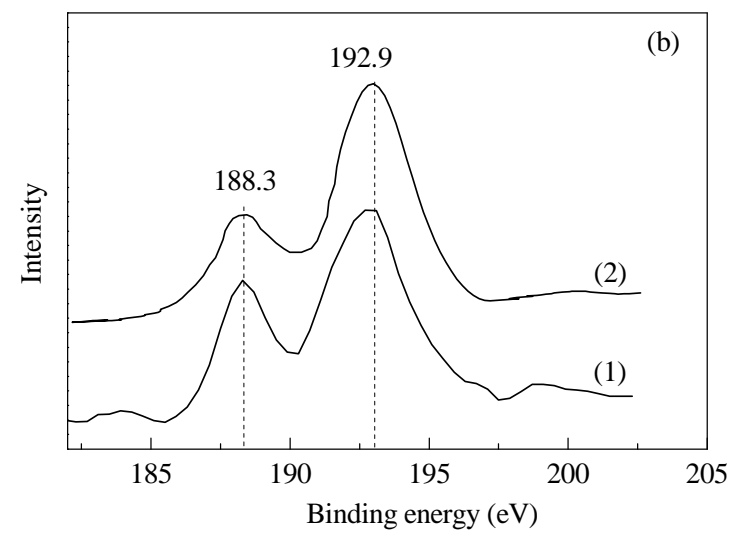

Fig. 2. Ru $3 d$ (a) and B $1 s$ (b) XPS of catalysts. (1) Ru-B-X/SBA-15; (2) Ru-B-C/SBA-15. 


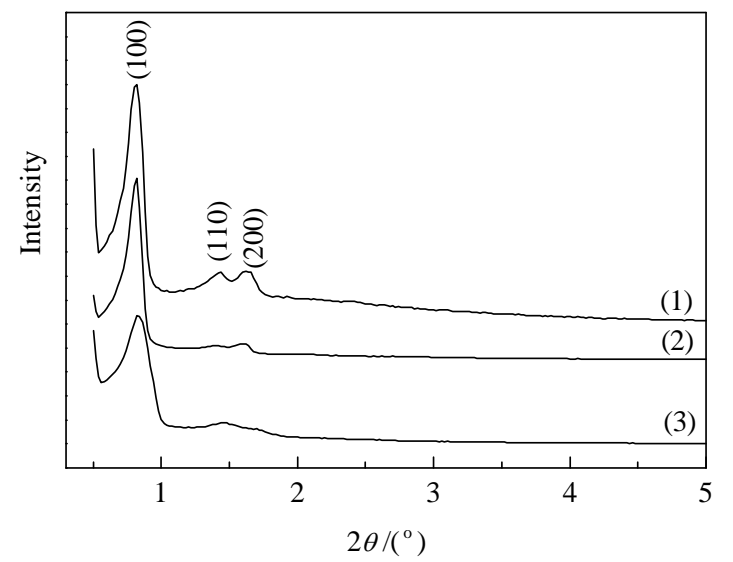

Fig. 4. Low-angle XRD patterns of the support and catalysts. (1) SBA-15, (2) Ru-B-X/SBA-15, and (3) Ru-B-C/SBA-15.

$1.4^{\circ}$ and $1.6^{\circ}$. This is indicative of (110) and (200) diffractions, which are characteristic of the 2D hexagonal $(p 6 \mathrm{~mm})$ structure [12]. Deposition with Ru-B nanoparticles caused significant decrease in the intensity of the diffraction peaks, implying the reduced ordering degree of the mesoporous structure, which were attributed to $\mathrm{Ru}-\mathrm{B}$ nanoparticles in the pore channels.

Figure 5 shows the TEM morphologies and SAED images (the inset) of Ru-B-X/SBA-15 and Ru-B-C/SBA-15. The SAED images showed that both samples displayed successive diffraction halos, indicative of typical amorphous alloy structure [17], in agreement with the above XRD characterizations. The TEM images demonstrated the ordered mesoporous structure. Remarkable particle agglomeration was observed in $\mathrm{Ru}-\mathrm{B}-\mathrm{C} / \mathrm{SBA}-15$, because some particles were larger than the pore diameter of SBA-15 that deposited on the outer surface of SBA-15. This was attributed to both the strongly exothermic reaction between $\mathrm{Ru}^{3+}$ and $\mathrm{BH}_{4}{ }^{-}$and the release of a huge mass of hydrogen during the catalyst preparation, which put the produced $\mathrm{Ru}-\mathrm{B}$ particles out of the pore. In contrast, the $\mathrm{Ru}-\mathrm{B}$ nanoparticles in Ru-B-X/SBA-15 were uniformly distributed within the mesoporous channels with much smaller size. This was attributed to the chelating of $\mathrm{Cl}^{-}$to $\mathrm{Ru}^{4+}$, which ensured that the reaction between $\left[\mathrm{RuCl}_{6}\right]^{--}$and $\mathrm{BH}_{4}{ }^{-}$occurred in a homogeneous and smooth manner, and therefore diminished the particle agglomeration. On the other hand, the smooth reduction reaction was favorable for the diffusion of hydrogen out of the pore, which prevented the $\mathrm{Ru}-\mathrm{B}$ nanoparticles from being moved out of the channel. As shown in Table 1, Ru-B-X/SBA-15 exhibited higher $A_{\text {act }}$ than $\mathrm{Ru}-\mathrm{B}-\mathrm{C} / \mathrm{SBA}-15$, owing to the absence of the large particles arising from the particle agglomeration. Moreover, both supported Ru-B samples displayed a higher dispersion degree of the $\mathrm{Ru}$ active sites, which could be understood by considering the dispersing effect of carrier [4].

\subsection{Catalytic performance}

Table 1 summarized some of the catalytic parameters over the different catalysts during liquid-phase maltose hydrogenation. All of the Ru-based catalysts displayed nearly 100\% selectivity towards maltitol. However, only 70\% selectivity was obtained on Raney Ni because of the formation of sorbitol and an uncertain byproduct at trace level. Sorbitol could be considered as the hydrogenation product of glucose originating from the hydrolysis of maltose [8], and the uncertain byproduct was possibly formed via the dehydration reaction between glucose molecules and maltitol molecules [8]. The poor selectivity of Raney Ni could be attributed to the presence of residual alumina [18], which served as acidic sites to catalyze the hydrolysis of maltose and the condensation between glucose and maltitol [8]. Compared with Ru-based catalysts, Raney Ni possessed a very high $A_{\text {act, }}$ but exhibited a much lower $R_{\mathrm{H}^{\mathrm{m}}}$ and a maltose conversion within $0.5 \mathrm{~h}$ because of the extremely low intrinsic activity $\left(R_{\mathrm{H}} \mathrm{S}\right)$. This suggests that Ru was much more active than

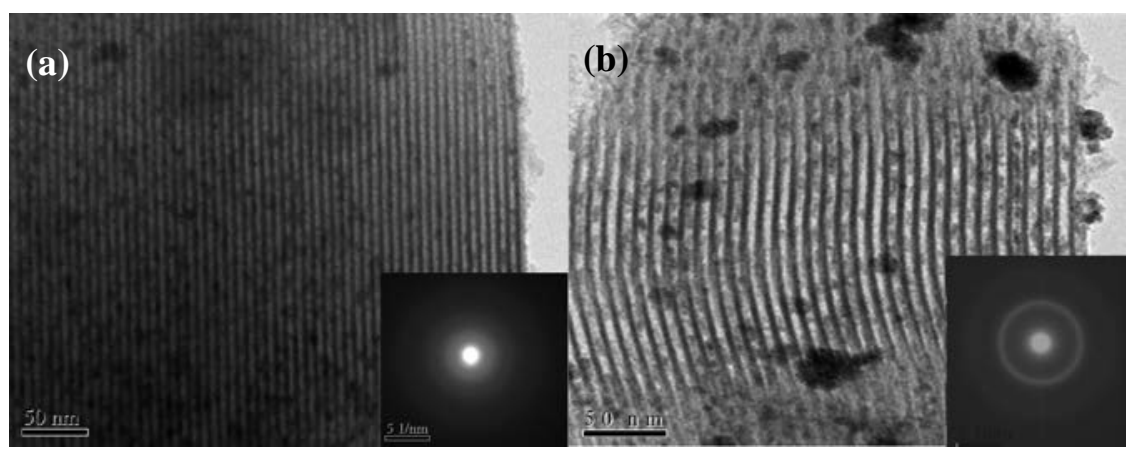

Fig. 5. TEM images of Ru-B-X/SBA-15 (a) and Ru-B-C/SBA-15 (b). Insets are the SAED patterns of the Ru-B particles.

Table 1

Structural characteristics and catalytic properties of the as-prepared catalysta.

\begin{tabular}{|c|c|c|c|c|c|c|c|}
\hline Catalyst & Composition & Ru loading (wt \%) & $A_{\text {act }}\left(\mathrm{m}^{2} / \mathrm{g}\right)$ & $R_{\mathrm{H}^{\mathrm{m}}}(\mathrm{mmol} /(\mathrm{h} \cdot \mathrm{g}))$ & $R_{\mathrm{H}} \mathrm{s}\left(\mathrm{mmol} /\left(\mathrm{h}^{\prime} \mathrm{m}^{2}\right)\right)$ & Conversion $(\%)$ & Selectivity (\%) \\
\hline Ru-B-X/SBA-15 & $\mathrm{Ru}_{74} \mathrm{~B}_{26}$ & 4.3 & 39 & 1062 & 27 & 99 & 100 \\
\hline Ru-B-C/SBA-15 & $\mathrm{Ru}_{75} \mathrm{~B}_{25}$ & 4.2 & 36 & 710 & 20 & 94 & 100 \\
\hline $\mathrm{Ru}-\mathrm{B}-\mathrm{C}^{\mathrm{b}}$ & $\mathrm{Ru}_{72} \mathrm{~B}_{28}$ & - & 7.1 & 133 & 19 & 14 & 100 \\
\hline Raney $\mathrm{Ni}^{\mathrm{c}}$ & $\mathrm{Ni}$ & - & 45 & 7.5 & 0.2 & 2 & 70 \\
\hline
\end{tabular}

a Reaction conditions: $1.0 \mathrm{~g}$ catalysts, maltose aqueous solution $(40 \mathrm{wt} \%, 50 \mathrm{ml}), T=373 \mathrm{~K}, p\left(\mathrm{H}_{2}\right)=3.0 \mathrm{MPa}$, reaction time $=0.5 \mathrm{~h}$, stirring rate $=1200$ $\mathrm{r} / \mathrm{min}$. ${ }^{\mathrm{b}} \mathrm{A}$ catalyst containing $0.05 \mathrm{~g} \mathrm{Ru} .{ }^{\mathrm{c}} \mathrm{A}$ catalyst containing $1.0 \mathrm{~g} \mathrm{Ni}$. 


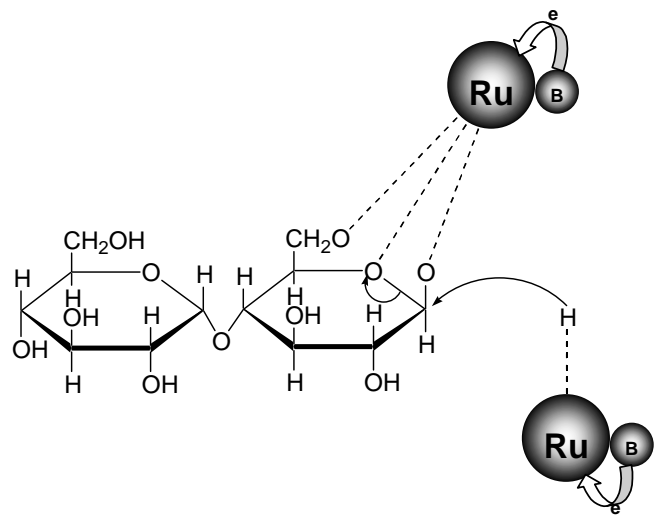

Scheme 2. Schematic representation of the reaction mechanism between adsorbed maltose and hydrogen on Ru-B amorphous alloy catalysts.

$\mathrm{Ni}$ in nature for maltose hydrogenation [8]. On the other hand, the superior intrinsic activity of the as-prepared catalysts could be attributed to their unique amorphous alloy structure, which had proven to be favorable for hydrogenation processes [4].

The $R_{\mathrm{H}} \mathrm{m}$ and maltose conversion within $0.5 \mathrm{~h}$ presented in Table 1 revealed that $\mathrm{Ru}-\mathrm{B}-\mathrm{C} / \mathrm{SBA}-15$ was much more active than $\mathrm{Ru}-\mathrm{B}-\mathrm{C}$, whereas the similar $R_{\mathrm{H}} \mathrm{S}$ values implied the same feature of $\mathrm{Ru}$ active sites in these catalysts. Accordingly, the superior activity over Ru-B-C/SBA-15 to Ru-B-C can be attributed to its higher active surface area $\left(A_{\text {act }}\right)$ due to the dispersing effect of carrier. Table 1 also revealed that Ru-B-X/SBA-15 exhibited higher activity relative to $\mathrm{Ru}-\mathrm{B}-\mathrm{C} / \mathrm{SBA}-15$. This may be due to both the larger metallic area $\left(A_{\text {act }}\right)$ and the enhanced intrinsic activity $\left(R_{\mathrm{H}} \mathrm{S}\right)$. Beenackers et al. [19] showed that, upon the adsorption of glucose on metals, an ionized species was generated (i.e., glucose anion), which was susceptible to attack by hydrogen adsorbed dissociatively on the neighboring metal sites, initiating the reaction. Wit et al. [20] confirmed the promotional effect of proton abstraction from the anomeric hydroxyl group on the hydrogenation of glucose. The adsorption and hydrogenation of the maltose molecule on Ru-based amorphous alloy catalysts could be described as in Scheme 2. The aforementioned XPS analysis

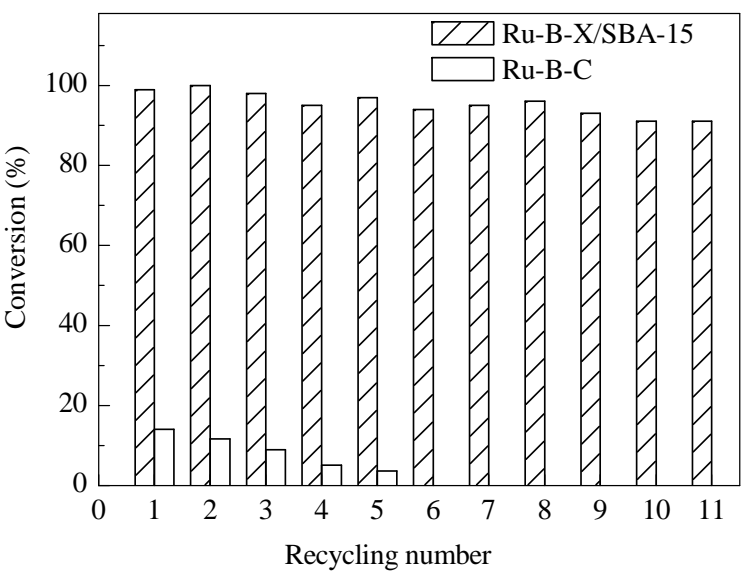

Fig. 6. Maltose conversion on Ru-B-X/SBA-15 and Ru-B-C as function of recycling runs. The reaction conditions are given in Table 1.

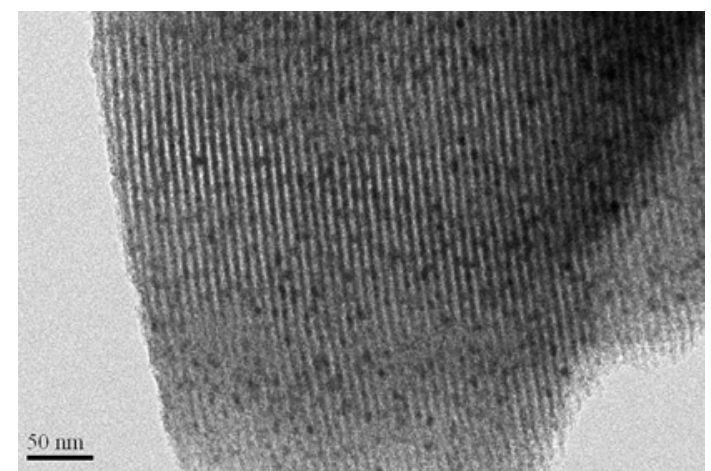

Fig. 7. TEM image of Ru-B-X/SBA-15 after 11 consecutive runs.

demonstrated that the $\mathrm{Ru}$ in $\mathrm{Ru}-\mathrm{B}-\mathrm{X} / \mathrm{SBA}-15$ was more electron-enriched than that in Ru-B-C/SBA-15, taking into account that $\mathrm{Ru}-\mathrm{B}-\mathrm{X} / \mathrm{SBA}-15$ was surface B-enriched compared with $\mathrm{Ru}-\mathrm{B}-\mathrm{C} / \mathrm{SBA}-15$. As a consequence, the higher electron density on $\mathrm{Ru}$ active sites might be favorable for the formation of $\mathrm{H}^{-}$species [21] and ionized maltose species, leading to the enhanced $R_{\mathrm{H}^{\mathrm{S}}}$.

Figure 6 shows the recycling tests using Ru-B-X/SBA-15 and Ru-B-C catalysts. A significant loss in activity (74\%) was observed for $\mathrm{Ru}-\mathrm{B}-\mathrm{C}$ after five recycles, whereas $\mathrm{Ru}-\mathrm{B}-\mathrm{X} / \mathrm{SBA}-15$ could be used repetitively 11 times with slight loss of activity (8\%). ICP analysis revealed that no leaching of Ru species could be detected for Ru-B-X/SBA-15 and Ru-B-C catalysts during repetitive uses, implying that both catalysts were stable against the chelating effect of reactant and product [22]. The transformation from an amorphous alloy structure to a crystalline structure has proven to be the main factor responsible for the deactivation of Ru-B-C [9]. According to this, the improved durability of Ru-B-X/SBA-15 over Ru-B-C could be attributed to its higher surface $B$ content and the stabilizing effect of carrier, therefore yielding better thermal stability, as confirmed by the aforementioned DSC analysis (Fig. 3). The high durability of Ru-B-X/SBA-15 can also be attributed to the interaction between $\mathrm{Ru}-\mathrm{B}$ and SBA-15, which retards the agglomeration of $\mathrm{Ru}-\mathrm{B}$ nanoparticles during the hydrogenation (Fig. 7).

\section{Conclusions}

In summary, the present work supplied a facile approach to synthesizing supported Ru-B amorphous alloy through a chemical reduction method using $\left(\mathrm{NH}_{4}\right)_{2} \mathrm{RuCl}_{6}$ as a ruthenium source. The $\mathrm{Ru}-\mathrm{B}$ amorphous alloy nanoparticles possessed higher surface B content and were homogeneously confined in the pore channel of SBA-15, which had been shown to have a positive influence on the catalytic activity in the hydrogenation of maltose to maltitol. Ru-B-X/SBA-15 exhibited superior durability to the conventional $\mathrm{Ru}-\mathrm{B}$ amorphous alloy during the hydrogenation of maltose, owing to the improved thermal stability. Our findings demonstrate the advantages of the present approach, making it possible to prepare highly dispersed and stable amorphous alloy, as well as the as-prepared $\mathrm{Ru}-\mathrm{B}-\mathrm{X} / \mathrm{SBA}-15$ amorphous alloy, to be a potential alternative to the traditional Raney Ni catalyst in the maltitol production process. 


\title{
Graphical Abstract
}

Chin. J. Catal., 2013, 34: 1027-1032 doi: 10.1016/S1872-2067(12)60526-9

\section{Synthesis of Ru-B amorphous alloy supported on SBA-15 with excellent catalytic efficiency in malt- ose hydrogenation}

WANG Yi, XU Liang, XU Lei, LI Hexing, LI Hui* Shanghai Normal University

Highly dispersed and stable Ru-B amorphous alloy was prepared by using $\left(\mathrm{NH}_{4}\right)_{2} \mathrm{RuCl}_{6}$ as ruthenium sources, which was a potential alternative to the traditional Raney Ni catalyst in maltitol production process.

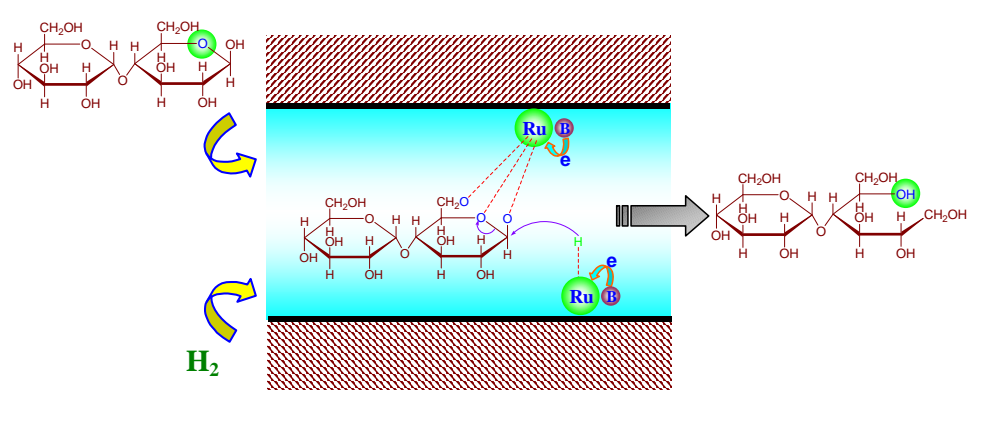

\section{References}

[1] Toufeili I, Dziedzic S. Food Chem, 1993, 47: 17

[2] Li H, Yang P F, Chu D S, Li H X. Appl Catal A, 2007, 325: 34

[3] Capet F, Comini S, Odou G, Looten P, Descamps M. Carbohydr Res, 2004, 339: 1225

[4] Deng J F, Li H X, Wang W J. Catal Today, 1999, 51: 113

[5] Pei Y, Zhou G B, Luan N, Zong B N, Qiao M H, Tao F. Chem Soc Rev, 2012, 41: 8140

[6] Sun H J, Guo W, Zhou X L, Chen Z H, Liu Z Y, Liu S C. Chin J Catal (孙 海杰, 郭伟, 周小莉, 陈志浩, 刘仲毅, 刘寿长. 催化学报), 2011, 32: 1

[7] Guo H B, Li H X, Zhu J, Ye W H, Qiao M H, Dai W L.J Mol Catal A, 2003, 200: 213

[8] Li H, Chu D S, Liu J, Qiao M H, Dai W L, Li H X. Adv Synth Catal, 2008, 350: 829

[9] Li H, Wang Y, Zhao Q F, Li H X. Res Chem Intermed, 2009, 35: 779

[10] Chen X, Wang S, Zhuang J, Qiao M H, Fan K N, He H Y.J Catal, 2004, 227: 419

[11] Li H, Xu Y, Yang H, Zhang F, Li H X. J Mol Catal A, 2009, 307: 105
[12] Zhao D, Feng J, Huo Q, Melosh N, Fredrickson G H, Chmelka B F, Stucky G D. Sciencce, 1998, 279: 548

[13] Schulz R, Van Neste A, Zielinski P A, Boily S, Czerwinski F, Szpunar J, Kaliaguine S. Catal Lett, 1995, 35: 89

[14] Fuggle J C, Madey T E, Steinkilberg M, Menzel D. Surf Sci, 1975, 52: 521

[15] Li H, Li H X, Dai W L, Wang W J, Fang Z G, Deng J F. Appl Surf Sci, 1999, 152: 25

[16] Li H X, Wang W J, Li H, Deng J F. J Catal, 2000, 194: 211

[17] Klein S, Martens J A, Parton R, Vercruysse K, Jacobs P A, Maier W F. Catal Lett, 1996, 38: 209

[18] Devre F, Hoffer B W, Sloof W G, Kooyman P J, Van Langeveld A D, Zandbergen H W. Appl Catal A, 2003, 244: 291

[19] Beenackers J A W M, Kuster B F M, Van der Baan H S. Carbohydr Res, 1985, 140: 169

[20] de Wit G, de Vlieger J J, Dalen A C K, Heus R, Laroy R, Van Hengstum A J, Kieboom A P G, Van Bekkum H. Carbohydr Res, 1981, 91: 125

[21] Noller H, Lin W M. J Catal, 1984, 85: 25

[22] Kusserow B, Schimpf S, Claus P. Adv Synth Catal, 2003, 345: 289

\section{高性能麦芽糖加氢Ru-B/SBA-15非晶态合金催化剂的制备}

\author{
王 奕, 徐 亮, 许 否, 李和兴, 李 辉*
}

上海师范大学资源化学教育部重点实验室和上海市稀土功能材料重点实验室, 上海200234

摘要: 以介孔氧化硅(SBA-15)为载体, 采用超声辅助 $\left(\mathrm{NH}_{4}\right)_{2} \mathrm{RuCl}_{6}$ 浸渍和 $\mathrm{BH}_{4}{ }^{-}$还原法制备了负载型 $\mathrm{Ru}-\mathrm{B}$ 催化剂, 并通过 $\mathrm{X}$ 射线衍 射、X光电子能谱、差示扫描量热法和透射电子显微等技术表征了该催化剂. 结果表明, 所制得的Ru-B-X/SBA-15催化剂具有非 晶态合金结构, 且Ru-B颗粒高分散在SBA-15的孔道中. 在液相麦芽糖加氢反应中, 与采用 $\mathrm{RuCl}_{3}$ 为金属源制得的Ru-B-C/SBA-15 相比, Ru-B-X/SBA-15催化剂具有更高的活性, 是非负载型Ru-B-C催化剂的7倍以上, 且能重复套用11次而未发生显著的失活. 关键词: 钉; 硼; 非晶态合金; 介孔氧化硅; 加氢; 麦芽糖; 麦芽糖醇

收稿日期: 2012-12-03. 接受日期: 2013-01-08. 出版日期: 2013-05-20.

*通讯联系人. 电话: (021)64322642; 传真: (021)64322272; E-mail: lihui@shnu.edu.cn 基金来源：国家自然科学基金(21273149), 教育部新世纪优秀人才支持计划(NCET-11-1052), 上海市科委和教委项目 (11JC1408900, 12490502800, 10SG41, 12YZ084).

本文的英文电子版由Elsevier出版社在ScienceDirect上出版(http://www.sciencedirect.com/science/journal/18722067). 